\title{
Erişkin yaşta tanı alan Gaucher hastalıklı bir olgu
}

\author{
A case of gaucher disease diagnosed at adult age \\ Gülsüm Akgün Çağlıyan Oktay Bilgir \\ İzmir Bozyaka Eğitim ve Araştırma Hastanesi, Hematoloji Kliniği, İzmir, Türkiye
}

\section{Öz}

Gaucher hastalığı, dalak karaciğer ve kemik iliğinde glukozilseramid birikimi ile karakterizedir. Hastalık otozomal resesif geçer ve lizozomal lipid depo hastalığıdır. Glukozilseramid hidrolaz (b-glukozidaz)'da genetik defekt sonucu retikuloendoteliyal sistem hücrelerinin lizozomlarda glukoseramid birikir. Gaucher hastalığında masif splenomegali ve sitopeniler görülür. 37 yaşında sitopeniler ve hepatosplenomegali nedeniyle hastanemize başvuran ve erişkin yaşta Gaucher hastalığı tanısı alan olgu sunuldu.

Anahtar Sözcükler: Gaucher, sitopeni, splenomegali.

\begin{abstract}
Gaucher disease is characterized by the deposit of glucosylceramide in the spleen, liver and bone marrow. This lipid lysosomal storage disease shows autosomal recessive inheritance and. Glucosylceramide is stored in lysosomal bodies of the cells of the reticuloendothelial system as a result of a genetic defect in glucosylceramide hydrolase (bglucosidase). Massive splenomegaly and cytopenias are seen in Gaucher disease. We presented a 37-year-old woman admitted to our hospital with cytopenias and splenomegaly and diagnosed as Gaucher disease in adult age.
\end{abstract}

Keywords: Gaucher, cytopenia, splenomegaly.

\section{Giriş}

Gaucher hastalığının klinik bulguları, azalmış bglikoserebrosidaz aktivitesi sonucu kemik iliği, dalak, karaciğer, akciğer, böbrek gibi organlarda glikoserebrosidin birikmesi ile oluşmaktadır1. Bu birikime bağlı olarak pansitopeni, hepatosplenomegali, pulmoner infiltratlar, kemik lezyonları, glomerüler lezyonlar gibi organ disfonksiyonu bulguları görülebilmektedir. Nörolojik tutuluma göre hastalığın 3 tipi bulunmaktadır. Tip 1 adult (nonnöropatik), Tip 2 infantil (akut nöronopatik), tip 3 juvenil (subakut nöronopatik) şeklindedir. Tip 1 bütün yaşlarda, Tip 2 ve Tip 3 daha çok çocukluk döneminde görülür. Tip 2 ve Tip 3 nörolojik tutulum nedeniyle daha kötü prognozludur $(1,2)$. Gaucher hastalığında kemik iliği baskılanması sonucu yada hipersplenizme bağlı olarak sitopeniler ortaya çıkabilir (3). Halsizlik nedeniyle baş-vuran ve erişkin yaşta Tip 1 Gaucher hastalığı tanısı alan olgu sunuldu.

\footnotetext{
Yazışma Adresi: Gülsüm AKGÜN ÇAĞLIYAN

İzmir Bozyaka Eğitim ve Araştırma Hastanesi, Hematoloji Kliniği, İzmir, Türkiye

Makalenin Geliş Tarihi: 10.06.2014 Kabul Tarihi: 14.07.2014
}

\section{Olgu Sunumu}

37 yaşındaki kadın hasta belirgin halsizlik ve karın ağrısı nedeniyle başvurdu. Öyküsünde şikayetlerinin çocukluk döneminde başladığı, daha önce sağlık güvencesi olmaması nedeniyle tetkik edilemediği öğrenildi. Şikayetleri yaşam kalitesini bozması nedeniyle hasta hiç evlenmemiş ve doğum yapmamıştı. Soy geçmişinde özellik yoktu. Fizik muayenesinde cilt soluktu, karaciğer kot altında $10 \mathrm{~cm}$, dalak ise inguinal bölgenin üzerinde palpe edildi. Diğer sistem bakıları olağan bulundu. Hemogramda lökosit: $5000 / \mathrm{mm}^{3}$, hemoglobin: 9.2 gr/dL, mcv: 87, trombosit: $67000 / \mathrm{mm}^{3}$ saptandı. Periferik yaymada normokrom normositer eritrositler, trombosit sayısı 70000 saptandı. Sedimantasyon 96 $\mathrm{mm} / \mathrm{h}$ bulundu. Biyokimyasal testleri normaldi. Batın ultrasonda karaciğer 260 mm, dalak 350 mm idi. Kemik iliği aspirasyonunda çekirdekleri eksantrik yerleşimli soluk ve geniş sitoplazmalı tipik Gaucher hücreleri görüldü (Şekil-a ve Şekil-b). Hastanın bglikoserebrosidaz enzim düzeyi düşük bulunurken, genetik analizinde heterozigot N370S ve heterozigot L444P mutasyonu saptandı. Nöroloji ve göz muayeneleri normal saptanan hastaya Tip 1 Gaucher hastalığı tanısıyla imigluseraz $30 \mathrm{IU} / \mathrm{kg} / \mathrm{gün}$ (1600 
IU/gün) dozundan iki haftada bir başlandı. 2 yıldır enzim replasman tedavisi alan olgunun son hemogramı lökosit: $6900 \mathrm{~mm}^{3}$, hemoglobin: $11.8 \mathrm{gr} / \mathrm{dL}$, trombosit: $92000 \mathrm{~mm}^{3}$ idi. Fizik muayenede karaciğer ve dalak boyutlarında gerileme saptandı. Ultrason kontrolünde karaciğer $50 \mathrm{~mm}$, dalak boyutu $40 \mathrm{~mm}$ küçülmüştür. Yaşam kalitesinde belirgin düzelme görülmüştür.
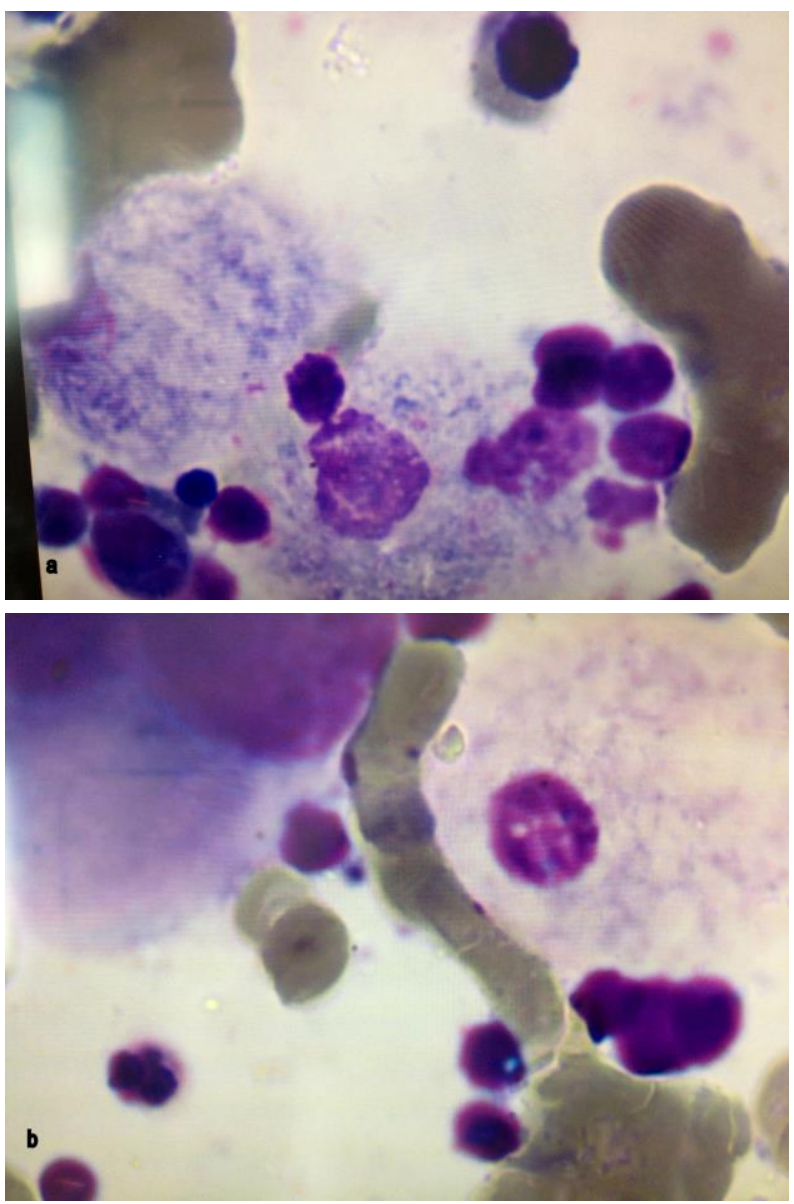

Şekil-1. a,b. Kemik iliği aspirasyonunda çekirdeği eksantrik yerleşimli, soluk ve geniş sitoplazmalı tipik Gaucher hücreleri.

\section{Tartışma}

Gaucher hastalığı glukoserebrozid birikimi ile seyreden, otozomal resesif geçiş gösteren, insidansı 1/40000 ile $1 / 100000$ arasında değişen, nadir bir lipid depo hastalığıdır. İlk kez 1882'de Ernest Gaucher tarafından tanımlanmıştır. Gaucher hastalığı Askenazi Yahudilerinde sık görülmektedir. Bu etnik grupta N370S, 84GG, L444P, IVS2, R463C mutasyonlarına sık rastlanmaktadır $(2,4)$.

Hastalığın üç klinik tipi vardır. Tip 1 kronik nonnöropatik tip tüm yaşlarda ortaya çıkabilir. Tip 1 Gaucher hastalığında masif splenomegali, hipersplenizm, hematolojik bulgular, tipik kemik bulguları görülürken santral sinir sistemi tutulumu görülmez $(1,2,5)$. Olgumuz Tip 1 Gaucher hastasıydı ve santral sinir sistemi tutulumu yoktu. Tip 2 akut nöropatik tip olarak bilinir. Santral sinir sistemi ağır olarak tutulur. Splenomegali ve çocuklarda gelişme geriliği görülür. Genellikle iki yaş altında ölümle sonuçlanır $(1,2,6)$. Tip 3 subakut nöronopatik tip, çocuklukta ortaya çıkar. Daha çok iç organ ve santral sinir sistemi tutulumu görülür. Ölüm 2040 yaş civarında görülmektedir $(1,2)$.

Tüm Gaucher hastalığı tiplerinde normokrom normositer anemi görülmektedir. Anemi, kemik iliği baskılanması sonucu yada hipersplenizme bağlı olarak ortaya çıkabilir. Ayrıca anemi kronik hastalık nedeniyle kısalmış eritrosit ömrü ve demir salınımında bozulma sonucu görülebilir. Gaucher hastalığında trombositopeniye bağlı kanamalar görülebilmektedir (6,7). Olgumuzda tanı anında normokrom normositer anemi ve trombositopeni vard, enzim tedavisi sonrası düzelmeler görüldü. Olgumuzda trombositopeniye bağlı kanama izlenmedi.

Gaucher hastalığında klinik bulgularla birlikte kemik iliği, karaciğer ve dalakta Gaucher hücrelerinin görülmesi ile tanı konur. Kesin tanı için enzim aktivitesi ile birlikte genetik analiz yapılmalıdır $(4,7)$. Olgumuzda kemik iliğinde çekirdeği eksantrik yerleşimli, soluk ve geniş sitoplazmalı tipik Gaucher hücreleri görüldü (Şekil1). Olgumuzun enzim düzeyi ve genetik analiz sonuçları Gaucher hastalığı ile uyumlu bulundu.

Tip 1 Gaucher hastalıklı olgularda b-glukoserebrosidaz enzim replasmanı tedavisi önerilmektedir. Plesantal yada rekombinant kaynaklı b-glukoserebrosidaz enzim replasman tedavileri ile kemik ve kemik iliği fonksiyonlarında düzelme, karaciğer ve dalak büyüklüğünde gerileme gösterilmiştir $(8,9)$. Hastamıza rekombinant bglukoserebrosidaz analogu olan imugluseraz enzim replasman tedavisi uygulanmıştır. Hastamızda enzim replasman tedavisi ile yaşam kalitesinde belirgin düzelme görüldü. Gaucher hastalığında bir diğer tedavi seçeneği ise hematopoetik kök hücre naklidir. Aslında allojenik kemik iliği nakli başarılı bir şekilde Gaucher hücrelerinin ilikten yok olması ve hastalığın klinik bulgularının düzelmesini sağlamaktadır. İlik nakli enzim replasman tedavisinden daha ucuz ve daha kalıcı bir tedavi şekli olmakla birlikte nakil sırasında fizik durumları en iyi olan hastalarda dahi \%10 mortalite olduğu bilinmektedir (10). Hastamızın HLA uygun allojenik vericisi bulunmamaktadır. Bu nedenle allojenik kök hücre nakli düşünülmedi.

Sonuç olarak, sitopeniler ve hepatosplenomegalisi olan erişkin hastalarda olası etiyolojik nedenler ekarte edildikten sonra, nadir de olsa Gaucher hastalığı akla gelmelidir. 


\section{Kaynaklar}

1. Beulter E. Gaucher disease: Multipl lessons from a single gene disorder. Acta Paediatr 2006;95(451):103-9.

2. Grabowski GA, Andria G, Baldellou A, et al. Gaucher disease: Presentation, diagnosis and assessment. Eur J Pediatr 2004;163(2):58-66.

3. Zimran A, Altarescu G, Rudensky B, Abrahamov A, Elstein D. Survey of hematological aspects of Gaucher diseases. Hematology 2005;10(2):151-6.

4. Kannai R, Chertok IR. Prenatal panel screening considerations for non-neuronopathic Gaucher disease in the AshkenaziJewish population. Isr Med Assoc J 2006;8(5):347-50.

5. Wenstrup RJ, Roca Espiau M, Weinreb NJ, Bembi B. Skeletal aspects of Gaucher disease: A review. Br J Radiol 2002;75 Suppl 1:A2-12.

6. Mignot C, Doummar D, Marie I, De Villemeur TB. French Type 2 Gaucher Disease Study Group. Type 2 Gaucher Disease: 15 new cases and review of the literature. Brain Dev 2006;28(1):39-48.

7. Germain DP. Gaucher disease: clinical , genetic and therapeutic aspects. Pathol Biol 2004;52(6):343-50.

8. Kaminsky $P$,Lidove O. Current therapeutic strategies in lysosomal disorder. Presse Med 2014;43(11):1174-84.

9. Van Dussen L, Biegstraaten M, Hollak Ce, Dijkqraaf MG. Cost-effectiveness of enzyme replacement therapy for Type 1 Gaucher disease. Orphanet J Rare Dis 2014 14;9(1):51.

10. Lecourt S, Mouly E, Freida D, et al. A prospective study of bone marrow hematopoietic and mesenchymal stem cells in type 1 Gaucher disease patients. PloS One 2013 Jul 25;8(7):e69293. 